\title{
The development of northern Sylt during the Latest Holocene
}

\author{
K.-A. Bayerl ${ }^{1}$ \& B. Higelke ${ }^{2}$ \\ ${ }^{1}$ Geologisches Institut, Universität Kiel; Olshausenstraße 40, D-24118 Kiel, \\ Federal Republic of Germany \\ ${ }^{2}$ Geographisches Institut, Universität Kiel; Ludewig-Meyn-Straße 14, D-24118 Kiel, \\ Federal Republic of Germany
}

\begin{abstract}
Former stages of the morphological development of northern Sylt are reconstructed to extend knowledge of the type and approximate time of the formation of a sandy bay (Königshafen) in the Wadden Sea. Apart from an analysis of historical maps and nautical charts, this paper includes the representation of the results of recent borings and sedimentological findings. The two ways of tracing back the development led to different conclusions, which are discussed. The cartographical conclusions cannot confirm the assumption that Königshafen was a deep bay. The input of dune sand from westerly directions and the formation of a sand spit system from the south have caused great morphological changes up to present times. Since the middle of the 17 th century there has been an extension of the Königshafen area. On the other hand, geological investigations show that the Ellenbogen could have been formed between the middle of the 17 th century and the end of the 18 th century. Before that, Königshafen was sheltered by a large sandy spit directly at the Lister Tief. It might have been the location of the famous sea battle of 1644 between the Danish fleet and a Swedish/Dutch fleet. The Königshafen area is possibly a young formation and is, at least since its separation from the Lister Tief by the Ellenbogen, an area of prevailing sedimentation.
\end{abstract}

\section{INTRODUCTION}

One of the goals of geoscientific investigations is the reconstruction of former stages of landscape development. This is fascinating in the geologically rather young coastal region in particular, because the border between land and sea can be subjected to rapid changes. Subsequent landscape transformations might have destroyed, covered, or integrated the evidence of a former state as relics into the recent coastal scenery. An especially interesting question is whether the region of Königshafen has been an area dominated by erosion or accumulation of sediment since the storm floods of the late Middle Ages. There are several methodological strategies to enable the reconstruction of such older stages. Field research allows us to draw conclusions about the special history of sediment dynamics in this coastal region from sediment stratigraphy or from an observed alternation of facies. On the other hand, one could try to find an older, lowerlying Wadden Sea surface with its sands and tidal channels. The preserved relics of reliefs from former phases of the development of the landscape can be determined and mapped. 
Old maps of the region allow a particularly good reconstruction of changes of the coastline. However, one has to compensate for mistakes, which are a constant feature of historical maps.

Apart from the description of more recent drilling results and sedimentological findings, the present study includes a current interpretation of historical sources. In connection with the evaluation of historical maps and nautical charts, we attempted to extend knowledge of the Königshafen formation with respect to its type and the approximate time of its formation. The two strategies used to solve the problem led to different results which will be discussed below.

\section{Geological overview and development during the Latest Holocene}

Geoscientific investigations have been carried out on the island of Sylt for over 100 years . The geological structure of the island and its environment is largely known (Meyn, 1876; Wolff, 1938; Gripp \& Simon, 1940; Dietz \& Heck, 1952; Köster, 1979). The Holocene development of the area around the island of Sylt has been the subject of extensive research (Gripp \& Simon, 1940; Priesmeier, 1970; Hoffmann, 1975; Köster, 1979; Averdieck, 1980; Willkomm, 1980). Pre-quaternary deposits are exposed at three sites on the island of Sylt. At the "Morsum Kliff", the most recent series of strata from the Upper Miocene (micaceous clay) to the Pliocene (kaolin sand) has been exposed for about 8 million years. Also at the "Weißes Kliff" near Braderup and at the bottom of the "Rotes Kliff" near Kampen, kaolin sands reach the earth's surface (Fig. 1).

The backbone of the island of Sylt consists of three cores of glacial deposits (till cores of Archsum, Morsum and Westerland) formed by the Saale Ice Age. The largest one is the Pleistocene core of Westerland in the centre of the island of Sylt (Fig. 1). The glaciers of the last Ice Age (Weichsel Ice Age, up to ca 10000 B.P.) did not reach the island of Sylt (Dietz \& Heck, 1952). Generally the Holocene series begins in the North of Sylt between 20 and $25 \mathrm{~m}$ below NN. The Holocene basement is composed of Eemian sediments (last interglacial episode) in extensive areas (Fig. 1). In the "Blidsel" channel, the Holocene series (mainly marine sand) reach a thickness of about $40 \mathrm{~m}$ (Gripp \& Simon, 1940). Taking the shifting dunes into account, the Holocene series has a thickness of up to $70 \mathrm{~m}$.

The Pleistocene core of Westerland has been, and still is, eroded by wave action and, in the progress of the Holocene, served as the starting point and supplier of sand for the southwards (Hörnum) and northwards (Listland) directed sand spits, which were formed by coastal dynamics as a consequence of the post-glacial rise in sea level (Gripp \& Simon, 1940; Köster, 1979).

In the shelter of the till cores and sand spits, marsh areas (Hoffmann, 1975) and characteristic barrier-type tidal flats developed (Bayerl, 1992). The phenomenon that the spits could be deposited almost vertically towards the deep tidal inlets which nowadays exhibit high current velocities and the fact that they were able to cross the former "Blidsel" channel in the North of Sylt are discussed in detail by Mager (1927) and Zausig (1939). Many authors consider the existence of islands having a core of limonite sandstone, mentioned by Meyn (1876) as being situated southwest of "Hörnum-Odde" and (north-)west of the "Listland", as a prerequisite for the formation of these sand spits.

Further open questions are the origin and time of formation of the "Ellenbogen" and Königshafen in the north of Sylt. These questions are of historical significance, too, 


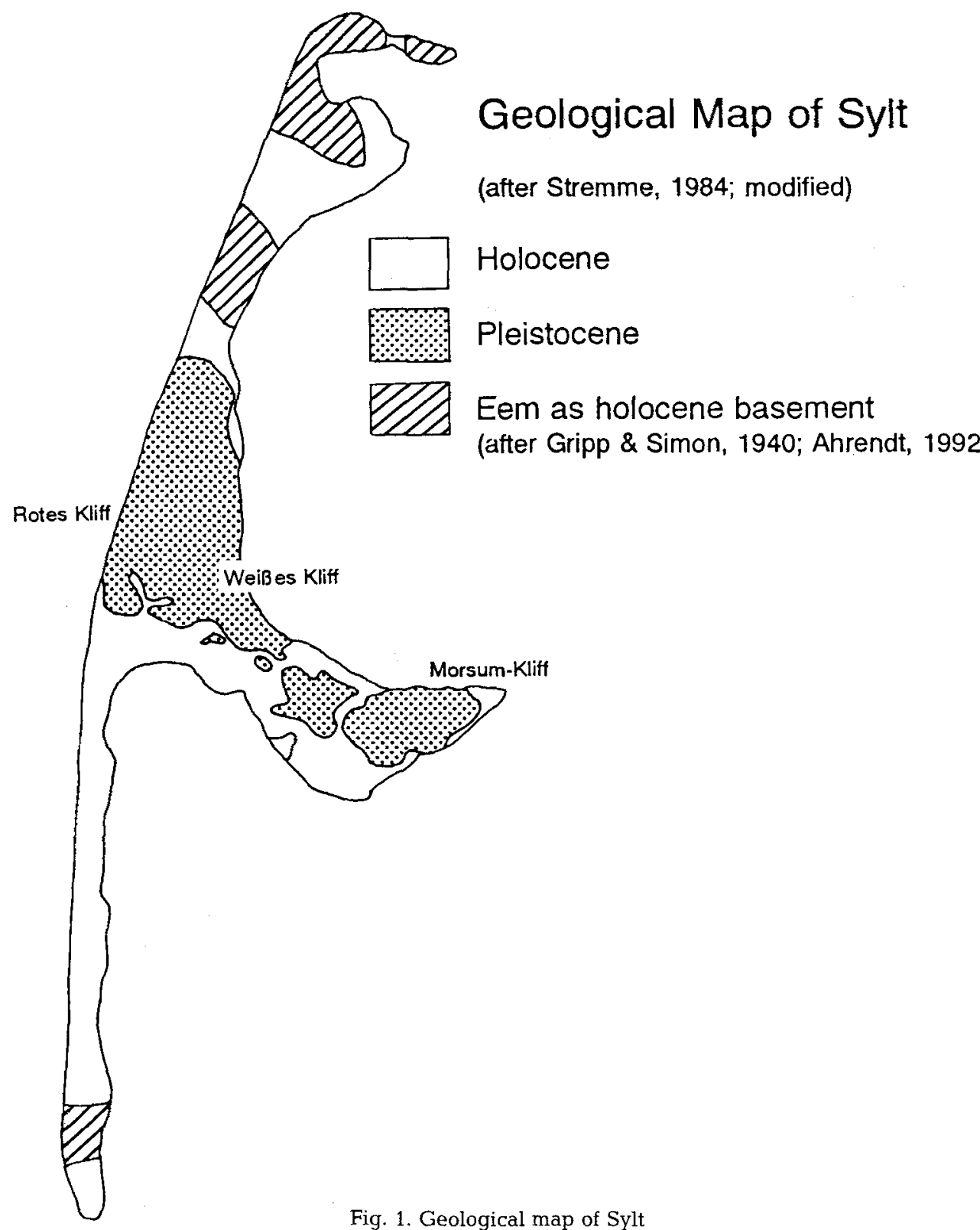

Fig. 1. Geological map of Sylt

because in August 1644 a sea-battle between a Danish and a Dutch/Swedish fleet is presumed to have taken place there, hence the name "Königshafen".

According to Danckwerth (1652), Königshafen was the most important and convenient harbour between the river Elbe and Skagen. Later references (Booysen, 1828) refer to strong sanding up within Königshafen, which made it useless for larger ships. Many 
other publications refer to the aeolian input of sand into Königshafen (Reinke, 1903; Nienburg, 1927; Kolumbe, 1933; Austen, 1990, 1992).

Mager (1927) and Zausig (1939) argue - on the basis of map comparisons - that the "Ellenbogen" formed after the sea-battle. The north-western edge of the island of Sylt ("Ellenbogen") remained nearly unchanged between 1740 and 1850 . Within this period, however, it lengthened significantly in an easterly direction (Hansen, 1845).

According to Gripp \& Simon (1940), Königshafen can be considered as a recess being left open during the continuous transport of material parallel to the coast from the Westerland Pleistocene core towards the north. According to Köster (1979), this Pleistocene core has receded about $10 \mathrm{~km}$ during the past 8000 years.

Priesmeier (1970) combined the development of the "Ellenbogen" with the formation of the "Salzsand", in the ebb delta of the "Lister Tief". He states that the filling up of the so-called "Blidsel-Tief", presumably a southern precursor of the "Lister Tief", proceeded in a similar manner. This would be accompanied by the formation of a primordial "Ellenbogen" and of a primordial "Salzsand", the latter being eroded again and, therefore, supplying material for the formation of North Sylt.

Priesmeier (1970) distinguishes four dune chains of the Listland, the oldest one, near the eastern shoreline, being $900-1200$ years old. The dunes of the Ellenbogen, not more than 300 years old, are ranked among the youngest dune chains formed.

The pre-industrial background of a sediment core from the "Mövenbergwatt" in central Königshafen can be localized at a depth $45 \mathrm{~cm}$ below the sediment surface (Höck \& Runte, 1992). This suggests a sedimentation of $45 \mathrm{~cm}$ during the past 120 years at the sampling site. Our own investigations on the recent reworking of sediments show a less pronounced tendency for sedimentation in the inner part of Königshafen.

\section{RESULTS}

\section{Cartographical approach}

The period of time documented in historical maps covers only the last 400 years. As maps are man-made pictures of the earth's surface, they allow us to detect peculiarities and details of the landscape that can - when using other geoscientific methods - often only be analysed and confirmed after their discovery in these maps. Comparing maps from different ages may be a useful tool to ascertain variations in the course of the shorelines over a certain time period. The surveying technique used for modern maps was not available in former times; therefore, the maps of the 16th and 17th centuries sometimes look strange. In order to trace the actual course of the coastline, the map has to undergo conscientious revision. Several publications (Lauridsen, 1903; Müller, 1938; Zausig, 1939; Lang, 1968; Newig, 1977, 1980a, 1980b) refer to this problem.

As far as the North-Frisian coast is concerned, the written sailing instructions were replaced by nautical charts in the middle of the 16th century (Lang, 1968; Witt, 1982). The contents of these maps which originated mainly from the Netherlands, were based on a few compass bearings and depth measurements and showed the course of the mainland and island shorelines in a rather arbitrary way. The precision of these maps increased during the following 200 years and reached a high standard towards the end of the 18th century. 
This development is demonstrated with sketch-maps of the investigation area showing the coastal morphology of North Sylt. They were drawn according to selected historical maps and reveal location and shape of Königshafen Bay (Fig. 2). In each of the eight outline maps, the location of the pictured part of the island is corrected to the map grid, and every outline is plotted at the same scale. Such a series of maps allows us to detect movements of the coastline and at the same time to observe the progress in land surveying and cartography.

The map of A. Haeyen of 1585 (Lang, 1973) shows that already at that time a bay existed in the region of today's Königshafen. Furthermore, the border of the navigable water is sketched in this part of the map. Haeyen had published a map for shipping purposes, the water depths being more important than the precise outlines of the land.

In the map of J. Mejer of the year 1648 (in the atlas of C. Danckwerth, 1652) things are completely different. It is a land map; thus, exact information about water depths is lacking, but the lines of the coastal shape are remarkably detailed. In this map, the bay of Königshafen is not simply indicated; it is represented graphically subdivided into several branches. It is striking that the name "Königshafen" has been inserted by Mejer north of the sand bar in the "Lister Tief" area. It should be noted that in the above-mentioned atlas of Danckwerth, several maps of Meyer are printed, each of them showing Sylt and the surrounding tidal flats in a slightly different manner. However, all the maps show the location, extension and topography of the island and mainland.

It is assumed that Niels Hegelund took the maps of Meyer as a model and carried out measurements in the "Lister Tief" to draw the first rather precise nautical chart in 1689 (Jepsen, 1977: p. 17).

Somewhat later, in the year of 1695, Jens Sörensen (Lang, 1973) investigated the depths of the shipping lanes of the western coast of Jutland. His map is based on compass bearings and distance measurements. This example shows how imaginative cartographers could be when drawing a coastline. The next example is the map of Du Plat et al., 1804. Newig (1977: p. 328) estimates that the land surveys were executed in 1793. This map has been commended for its preciseness. The same is true of the map of the Royal Scientific Society dating from 1805 (Bugge \& Wilster, 1805), which is based on the same surveys as the map of Du Plat. In both cases, the method of triangulation replaced the method of astronomical localization used for surveying the topography. Depth measurements in the tidal channels carried out by Holst \& Tuxen around 1807 (see Fig. 2) enabled them to produce a very exact nautical chart. Each of the three sources provides information so that one can picture their special shape and the location of the tidal channel and the island of Uthörn.

The state of the bay in 1870 (shown in another sketch) is based on the first depth measurements carried out by an officer of the Prussian Navy (Lang, 1973). With critical evaluation of the course of the coastline and the shape of the tidal channel, the result of this survey seems less precise than the map of Du Plat and his contemporary colleagues.

This becomes more clear in the example from 1909. The basis for the picture of this stage is the survey for the first Prussian nautical chart on the scale of 1:50000, which was carried out in 1904. The morphology of the shore in the inner bay, called "Kleiner Hafen", the winding course of the tidal channel and the island of Uthörn make a qualitative comparison easier than with that of Grapow from 1870. The present stage has been evaluated on the basis of surveys dating from 1991. The south has been diked 


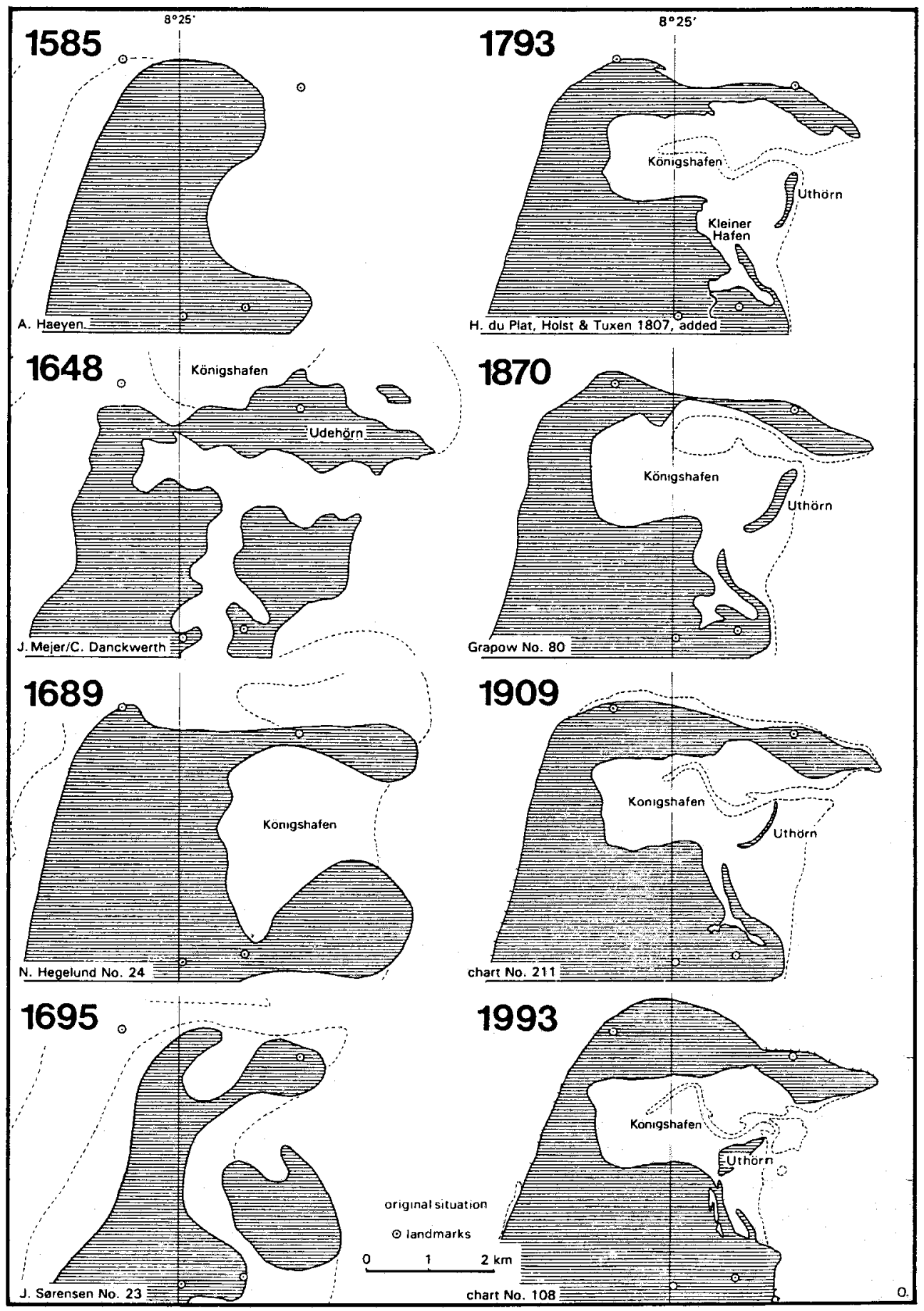

Fig. 2. Northern Sylt in old maps. Stippled line indicates border of navigable water or spring low tide line. For reliability see text 
in the meantime and the area of the island of Uthörn has been enlarged by sand replenishment.

For a comparison of the maps in order to fulfill the above-mentioned goal and to detect changes of the landscape, it is necessary to choose as long a time period as possible. In other words, the map showing a historical stage of landscape genesis has to be as old and precise as possible. After presenting a few examples it is understandable that the oldest nautical charts (e.g. that of A. Haeyen of 1585) are less suited for that purpose than are the land maps (of Mejer, about 1650) published somewhat later.

The map of Mejer is detailed but appears to be disproportioned. An intensive examination of the cartography of J. Mejer has shown that he often could not correctly reflect the relative location of the topographic details in his maps, because advanced techniques of site localization were not available at that time. The cartographic representation thus seems a little strange, because the positions of the landscape features show a varying displacement with respect to distance and direction (Higelke, 1986). Thus, the shape of North Sylt appears to be more compact than it is in reality.

It is therefore necessary to have reference points to adjust the position of each topographic element that has been drawn in the above map. Only such corrected maps can be compared with more recent ones in order to detect changes of the landscape.

The location of administrative and communal boundaries has always been of great importance. They are drawn with corresponding preciseness in the maps. J. Mejer noted the boundaries in some of his maps $(1648,1650,1651)$ and it makes sense to mark these boundaries, as positions of reference, with two points. Location and orientation of the boundary lines can be used for the reconstruction of a map (Fig. 3). Consequently, the island area of Sylt can be divided along one of these boundary lines (see reference points 6 and 7 in Fig. 3), and the northern part of the island can be moved to the north. The original shape of the island documented in the map of Mejer can be stretched in that way and can then be compared with the outline of the island in the corresponding maps of the "Deutsche Grundkarte" (1:5000). In this way, the reference points 8, 9, 10,11 and 12 can be identified. They represent topographical elements which are already present in Mejer's maps - such as road junctions and bends, an old farm house, or the point of intersection between the border of the till core and a path.

Even with these corrections, the shape of the island in the year 1650 seems to be slightly too broad in the region of Kampen, but the loss of land that without doubt occurred at the western coast after that has to be taken into account.

Making the corrections in the southern part of the map is a good exercise, because then the adjustment of the cartographic representation in the Königshafen area follows. A proposition concerning the manner of using the maps of Mejer for the analysis of recent landscape transformations is given by Newig (1980b, pp. $71 \mathrm{f}$.). He has tested all the attempts undertaken earlier and after that presented his own version for North Sylt. Following his explanations, the latitudinal position of each landscape element within the geographical net is given rather well. The representation of the northern tongue of land allows us to speculate whether it represents today's "Ellenbogen" or the island of Uthörn (=Udehorn as noted by Mejer himself). Questions arise regarding the island of Mellhörn at that time in the maps of Mejer.

The methodological approach suggested by Newig may be developed further. Using field observations and the analysis of maps with scales of $1: 5000$ and $1: 25000$ (Landes- 


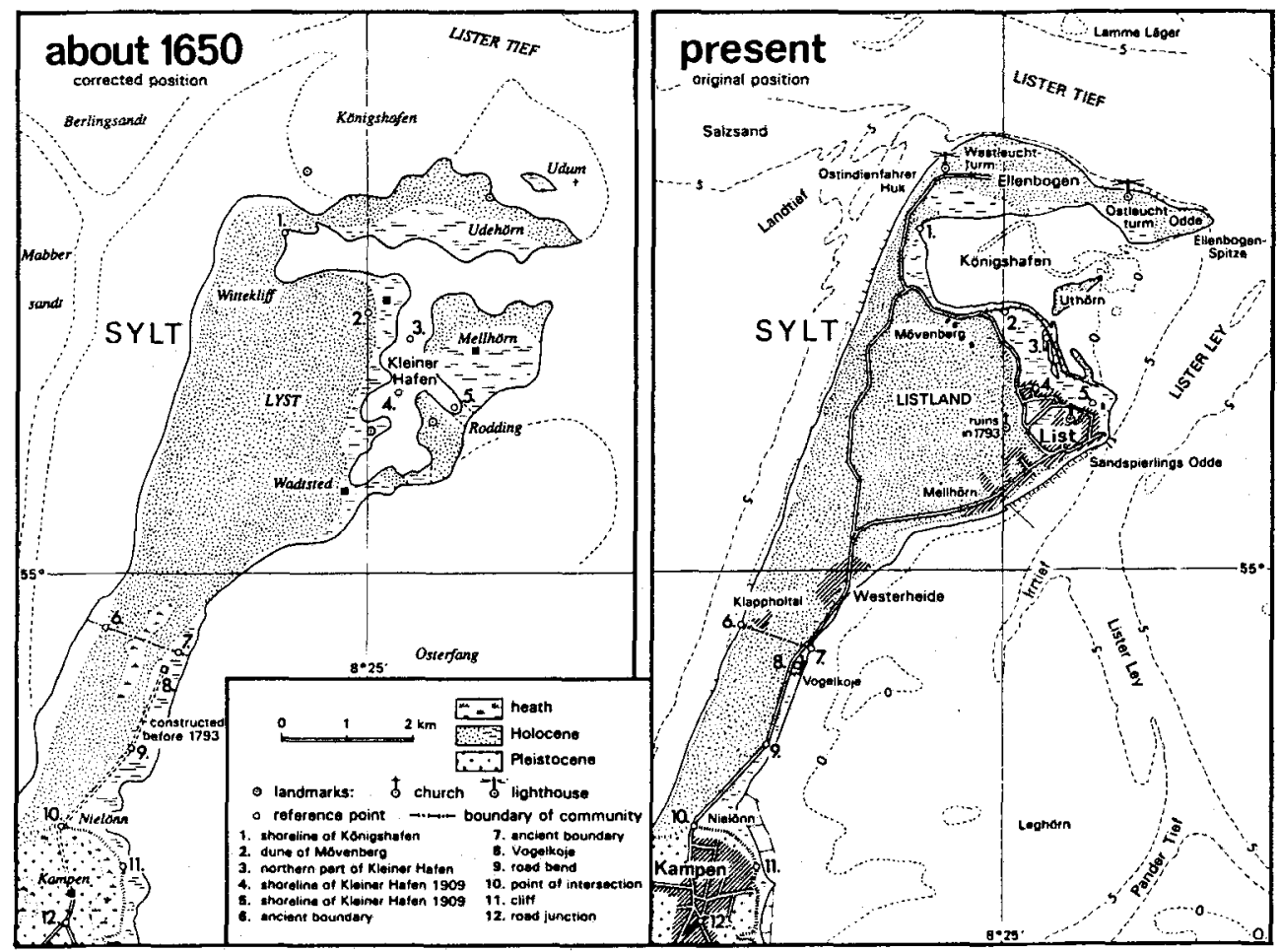

Fig. 3. Reconstruction after maps of J. Mejer

vermessungsamt Schleswig-Holstein, 1980), the landscape could be reconstructed as shown in the map for 1650 (Fig. 3, left). It is an attempt to utilize the entrance and the shores of the characteristic branches in the area of "Kleiner Hafen" as additional reference points (Fig. 3, points 3,4 and 5). The dune of the "Mövenberg", close to the present sewage treatment plant, was at that time not separated from the dune terrain - as can be seen on the map of Du Plat for 1793; therefore, it can be used as a reference site, too (point 2). Thus, the remains of the former landscape (which can still be found today) may help to adjust cartographic representations on old maps.

Searching for the relics of the branches of Königshafen bay, one has to look beyond the harbour grounds to the south-east. In the south, these relics are partly covered by the village of List (Fig. 3, right).

The ruins of the former church, the position of which is marked in the map for 1793 of Du Plat, confirm the statement resulting from the map analysis (points 4 and 5). Up to now, a high dune cliff, situated near the cross-roads at the "Kurverwaltung" in List, and the remains of the low plain, just in front of it, can be detected. A major part of the material of which the former island Mellhörn consisted may have been used to build the multisectional system of spits and sand-bars that extend in a northerly direction into Königshafen. This was comprehensively investigated by Kolumbe (1933, p. 121).

It is more difficult to determine the reference point 1 . It is indispensible, because it supplies a fixed point in the northern part of the map. The experience gained by the 
evaluation of the maps of Mejer allows us to equate the typical meandering shoreline (in Mejer's map) with the present shoreline at this site. It can also be assumed that, for a period, the opening existed in this area. Taking northwesterly winds and high tides into account, it would be easier to understand that, in this principally rather sheltered bay, currents and wave action were responsible for shore erosion and transportation of material. The road running south of the "Mövenberg" (point 2) marks the dune border to the "Kleiner Hafen". The water surging against it could have created this border in spite of sand-drift taking place here.

The comparison of two aerial photographs dating from the years 1936 and 1989 reveals the role of human-beings in the later phase of the transformation of the bay (Fig. 4). Both photographs were adjusted to the same scale and they show how the terrain of "Kleiner Hafen" in the southern part of Königshafen appears in the year 1936, before and after the embanked area filled up by sedimentation. This anthropogenic landscape variation is also documented by the strikingly large area of the island of Uthörn, which has been built up to this size for military reasons by artificial replenisnment with material from the eastern tidal gully. The summary of all results concerning map analysis and morphological landscape observation allows the following statement to be made: the evaluation of historical map material is rewarding. In particular, the maps of J. Mejer offer a good approach for thorough investigations, because of their age and their details. His maps are not products of fantasy, even if their precision is poor in comparison with today's standards. The result of the evaluations, together with the findings in the field, are not suited to proving the assumption of a deep bay. On the contrary, the shoreline bordering the shallow water has changed markedly, mainly in the south during the years 1650 to 1793 . The input of dune sand from the west, and the formation of sand-bars from a southerly direction, led to pronounced transformations. Map analysis shows, at the most, an extension of area in the region of the recent Königshafen, which is, however, not comparable with the transformations in the former southern part of this bay.

\section{Geological approach}

Geological profiles give insight into the subsoil and indications for the geological development of a region. The locations of the major part of the available boring profiles are shown in the overview map of North Sylt (Fig. 5). This map should provide an impression of the boring site density and their uneven distribution. The register of drillings was mostly taken from the boring records of the ALW. Husum as well as from Austen (1990).

A west-east profile with a length of more than $3500 \mathrm{~m}$ begins at the western edge of the "Gröningen" salt marsh and runs in an east-south-easterly direction to the western end of the "Lister Koog" dike. From here, it runs in an easterly direction over the "Mövenberg" and "Uthörn" to the western fringe of the "Lister Ley". Since 1938, considerable anthropogenic changes in the southern Königshafen area have occurred, caused by diking of the "Lister Koog", the sand replenishment of the island of Uthörn and the erection of buildings upon the "Mövenberg". Since many borings of this profile were carried out up to 1938, the topography at that time is shown and the recent one appears as a broken line (Fig. 6).

The west-east profile from the "Gröningen" salt marsh to ca 500 m east of Uthörn 


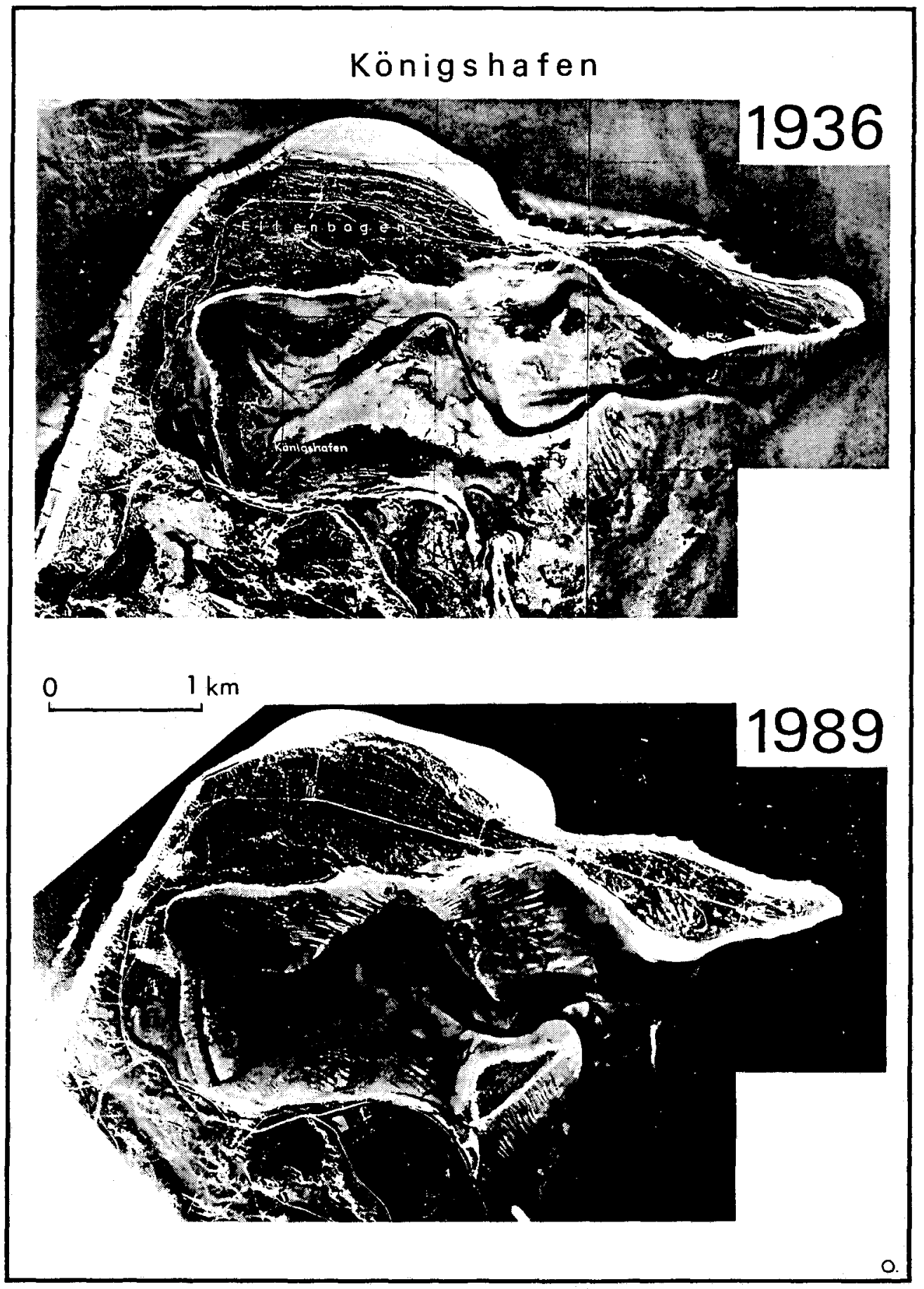

Fig. 4. Recent changes. Aerial photographs of 1936 and 1989 


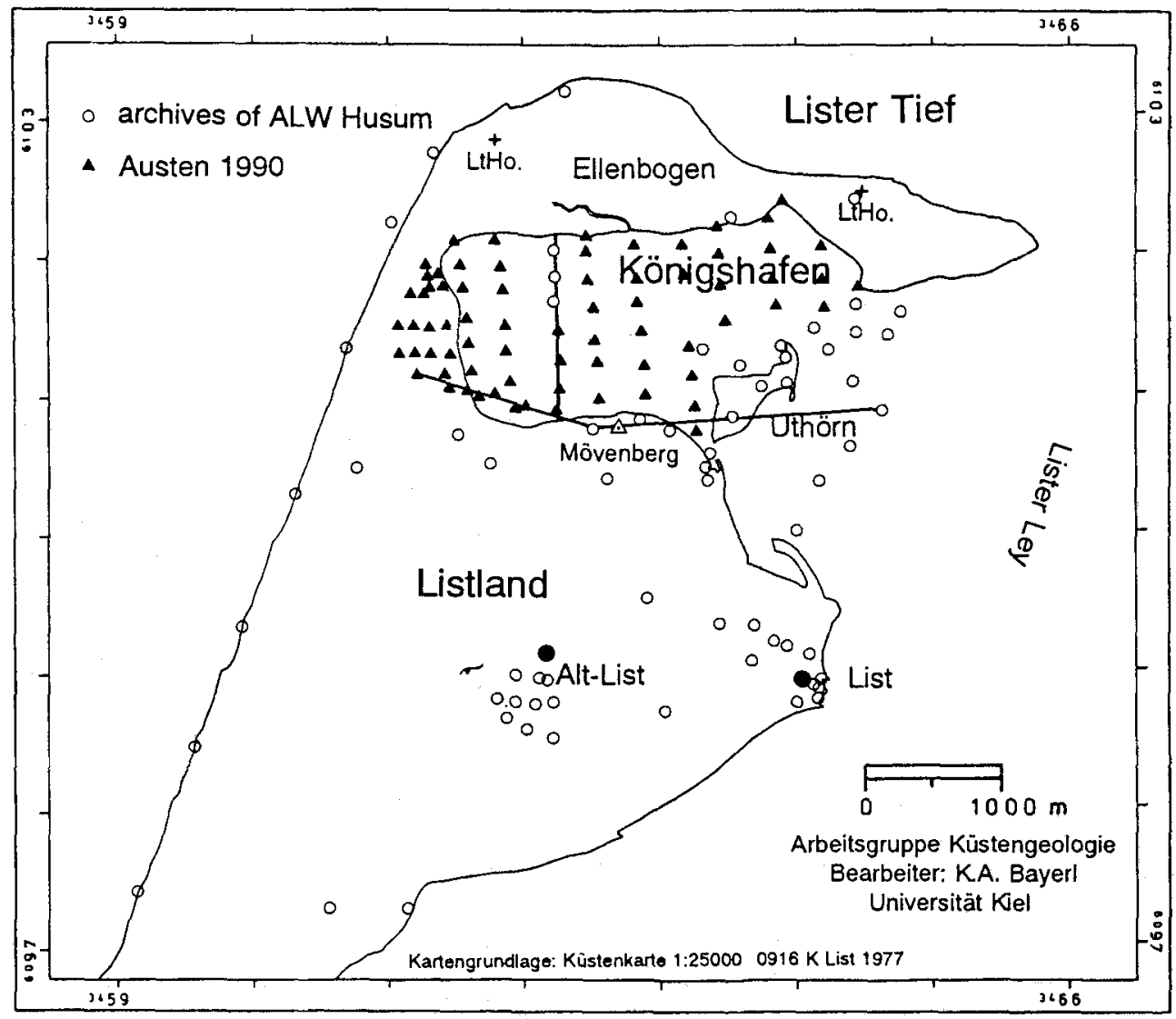

Fig. 5. Location of boring sites and profiles

exhibits a marked change in the series from fine-sandy or muddy intertidal sediments to mostly medium-grained dune sands (Austen, 1992; Goldschmidt et al., 1993) and sandbars consisting of coarse sand to fine gravel (Fig. 6). At the eastern edge of the "Gröningen" salt marsh, after a short distance in a northerly direction, a mud flat area reaching up to the tidal flat surface occurs. The borings in the middle of the profile run along the dike of the "Lister Koog", for which they were carried out up to 1938. Immediately east of the "Mövenberg" a relatively deep furrow filled with muddy deposits stands out. Another small furrow, partly filled with gyttja and reed remains, has been detected below the island of Uthörn by boring. Around $500 \mathrm{~m}$ in an easterly direction, the coarse sediments run out into a wedge, and characteristic intertidal sediment (fine sand) extends up to the tidal flat surface.

The north-south profile, with a length of ca $1300 \mathrm{~m}$, crosses Königshafen approximately $500 \mathrm{~m}$ east of the youth hostel (Fig. 5). At this site, intertidal sandy sediment extends continuously down to ca $-4 \mathrm{~m} \mathrm{NN}$ (Fig. 7). An extensive layer of clay, a few centimetres thick, covers the tidal flat sand in this area. At a distance of appr. $400 \mathrm{~m}$ from the southern shore, this layer reaches a thickness of more than $2 \mathrm{~m}$. In the middle of the 


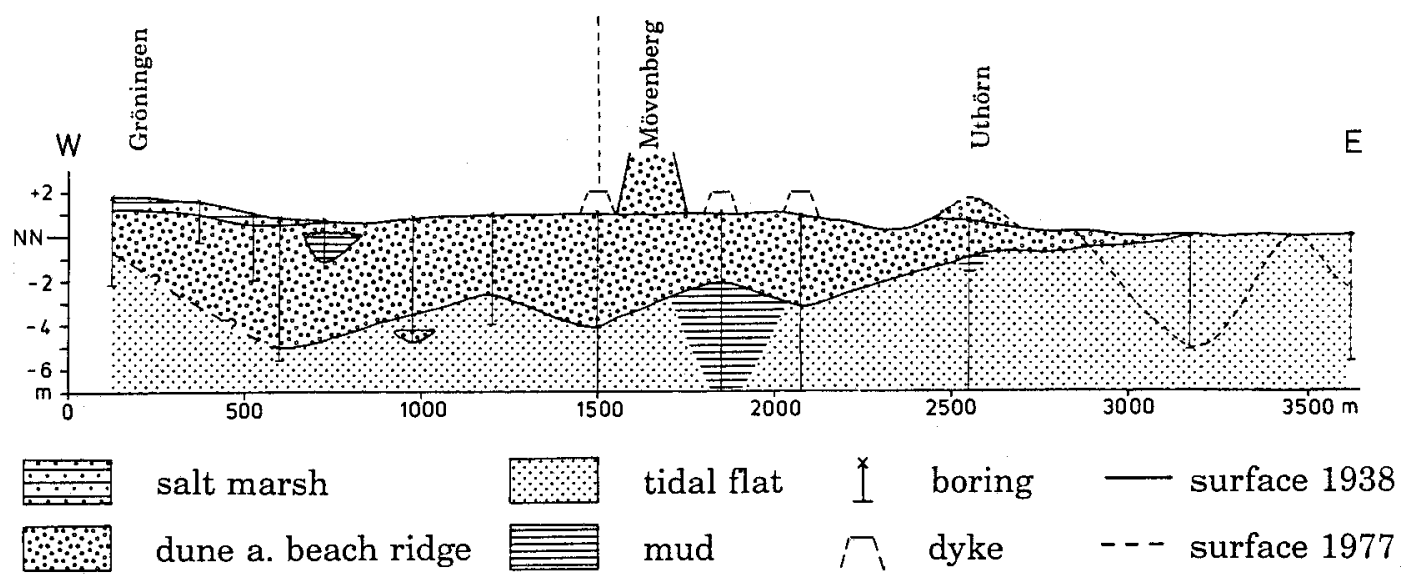

Fig. 6. Geological west-east profile across Königshafen. West of the "Mövenberg", the profile changes direction

profile up to the surface, the clay layer is followed by intertidal sands and by dune sands and sand-bar deposits in the nearshore regions. The latter ones occur intermittently between the dune sands at $-1 \mathrm{~m}$ and $\mathrm{NN}$ and extend from the northern and southern beaches for more than $400 \mathrm{~m}$ into Königshafen. Thus, from a northern direction they stretch to the tidal channel which bifurcates at this site. Accordingly, in the central part of Königshafen west of Uthörn, between ca $-1 \mathrm{~m}$ and $-4 \mathrm{~m} \mathrm{NN}$, a peculiar change of facies, from fine grained intertidal sediments $<0.2 \mathrm{~mm}$ to primarily aeolian medium grained sand, occurs.

The distribution of clay-silt deposits (clay, also gyttja) in depths of $-4 \mathrm{~m}$ to NN, readable from boring records, reflects formerly sheltered intertidal areas and lagoons under a cover of uniform thickness consisting mainly of dune sands in the region of the "Listland". Only those clay layers that are at least $10 \mathrm{~cm}$ thick are considered. The range of thickness is small, in contrast to the chosen depth range, because according to Priesmeier some shifting dune chains must have moved across the "Listland" into the

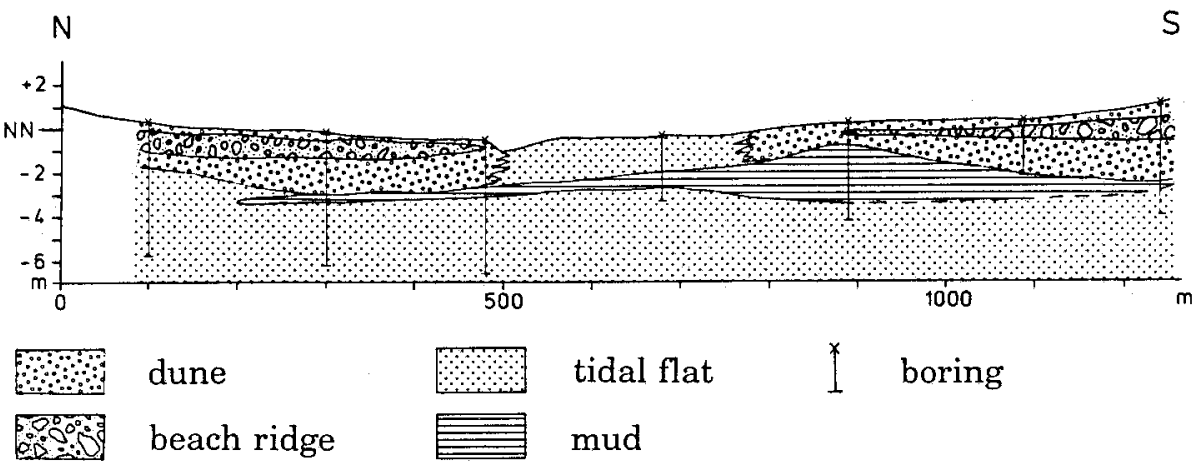

Fig. 7. Geological north-south profile across Königshafen 
recent intertidal area. Thereby, the initially very soft, muddy deposits were consolidated and - depending on the consistency of the subsoil - also dislocated vertically. The depth range of 0 to $-4 \mathrm{~m} \mathrm{NN}$ should also apply to terraces in small furrows or basins.

In the central part of Königshafen, clay is commonly found in the borings (Fig. 8), mostly below dune and intertidal sands. According to Austen (1992), muddy intertidal sediment extends to the surface in the western part of Königshafen ("Gröningwatt"). The thickness amounts to less than $1 \mathrm{~m}$ (cf. Fig. 7). At the north-western edge of Königshafen, the clay-silt deposits reach a thickness of more than $4 \mathrm{~m}$. Somewhat east of the "Mövenberg" a narrow connection probably exists between the clay deposits of Königshafen and the clay layers known from single borings in the "Lister Koog" (boring 11, 75 and 88: Dietz \& Heck, 1952) and near the youth hostel (boring 90 and 96: Dietz \& Heck, 1952). Possibly the furrow continues in a northeasterly direction to the clay and gyttja layers below Uthörn (cf. Fig. 6). A second clay deposit is known further south, by the boring at the "Brunnenfeld" in the valley of "Mannemorsum". In the dune valley, where the settlement of Alt-List (TK 25, Nr. 0916 List, 1986) is situated, clay-silt and fine grained sediments sporadically come to the surface a little above $\mathrm{NN}_{\text {, }}$ at the entrances of rabbit

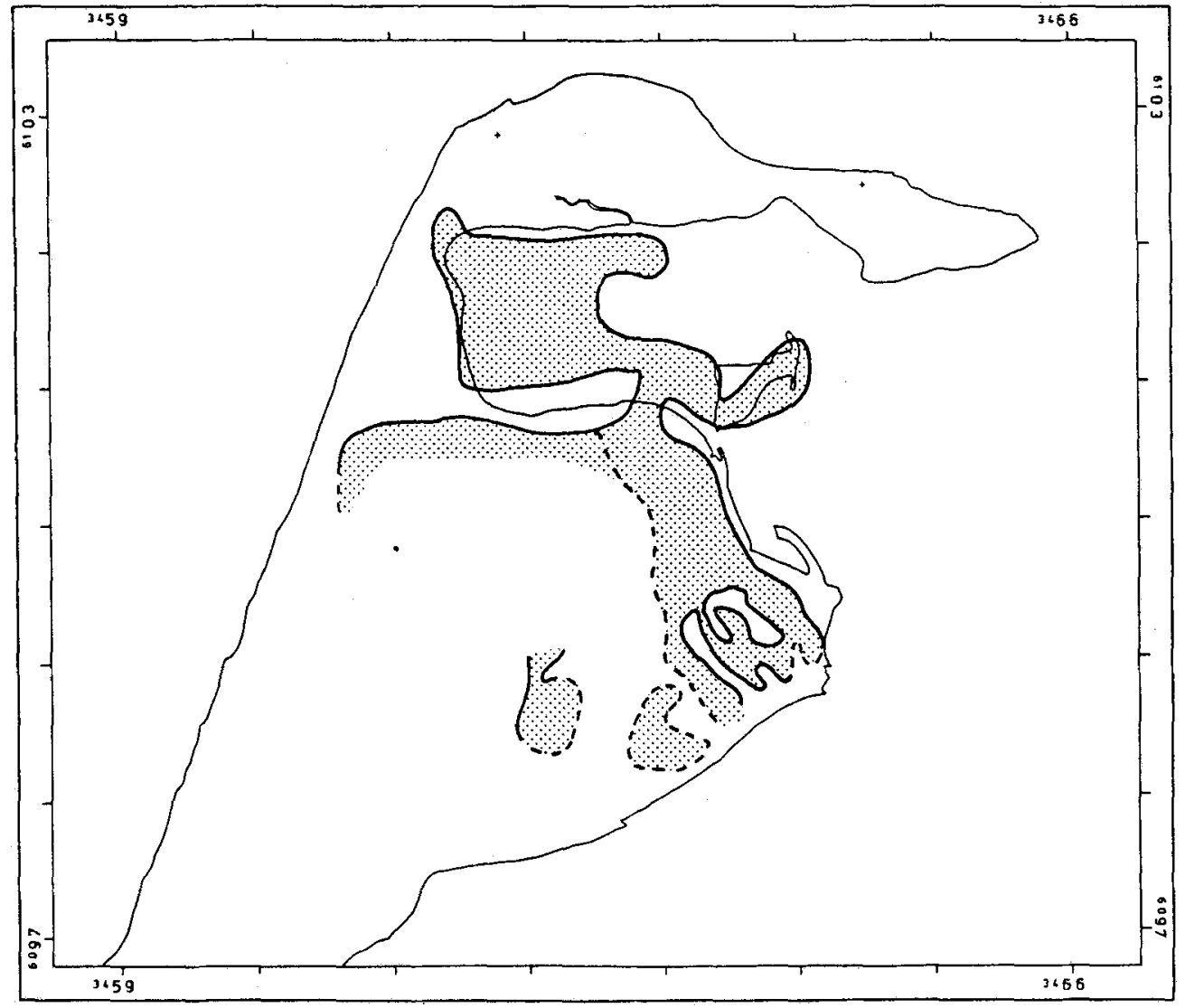

Fig. 8. Distribution of clay (gyttja) in the "Listland" between 0 and $-4 \mathrm{~m} \mathrm{NN}$ 
burrows. In the bordering, dune-covered region of the dune valley, lying somewhat above NN east of the "Sütterknoll", clay has been bored below sand-bar deposits and dune sand (boring 92: Dietz \& Heck, 1952).

The mapping-out of the sand bar deposits (medium sand with partly high percentages of coarse sand, mussel shells and gravel), known from borings, sediment cores, and depth exploration, is shown in Figure 9. Sand bars reflect the coast line. Their distribution around the level of the recent mean sea level - together with the comparison of historical maps - possibly allows for the reconstruction of the stages of former coastlines.

According to Kolumbe (1933), the sand-bar deposits in the present village of List can be attributed to a northerly transport of sand along the east coast of the "Listland". At the western beach, on the "Ellenbogen" and in the northern part of Königshafen they are widespread too. In central Königshafen, the coarse grained sand-bar deposits are limited to the shore region and, in many cases, extend to the tidal channel at the northern shore. At the south-eastern edge of Königshafen, in the latitude of the youth hostel, they form a narrow neck of about $200 \mathrm{~m}$, which widens to about $700 \mathrm{~m}$ into the "Mövenberg" tidal area towards the east. This neck was possibly connected to the northern sand-bar

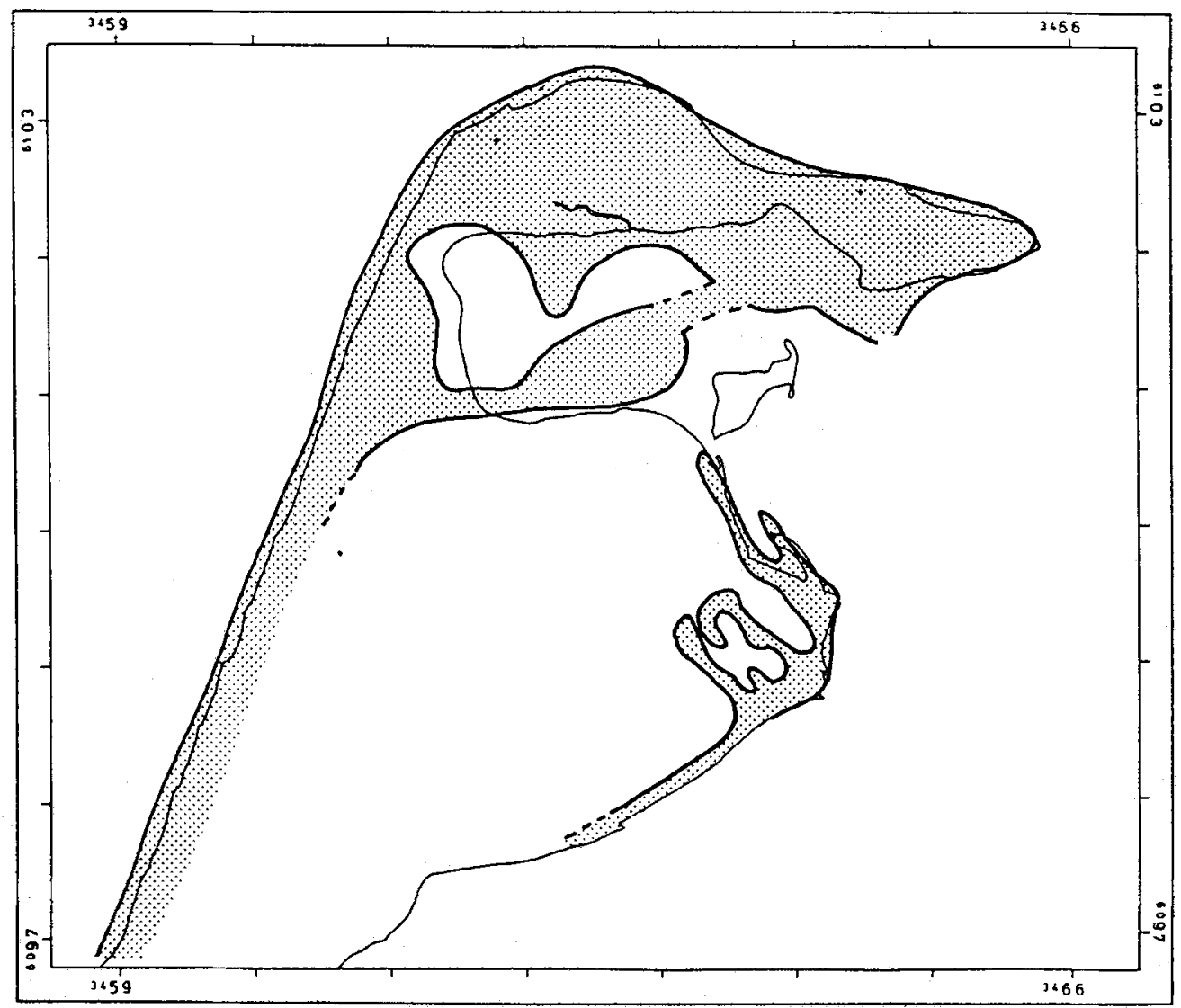

Fig. 9. Distribution of sand-bar deposits in the "Listland" between $-1 \mathrm{~m}$ and $+1 \mathrm{~m} \mathrm{NN}$ 
deposits, before being eroded by the tidal channel. On the southern shore of Königshafen, the sand-bar sediments extend to the channel north of the "Mövenberg" (cf. Fig. 6). The gravel beds lying at the sediment surface on the eastern shore of Uthörn are not considered in this description, because they are most probably a consequence of the sand replenishment at Uthörn during the Second World War.

The reconstruction of the former intertidal and lagoon areas, at present mostly covered with dunes in the "Listland" (Fig. 8) and sand-bar deposits (Fig. 9), offers - in conjunction with the comparison of historical maps and nautical charts - another possibility to understand the changes of the coastlines of North Sylt after 1648 (Fig. 10). The coastline in 1649 (J. Mejer in Danckwerth, 1652) is drawn as a broken line. The precursor of the "Ellenbogen" would lie at the southern shore of the recent Königshafen, would stretch in an eastern direction over the island of Uthörn ("Udehorn") and would have an appendix directed towards the north into the intertidal region.

A precursor of the Königshafen runs as a narrow inlet directly north of the present village of List, touching the youth hostel towards the west. An inlet of equal size runs

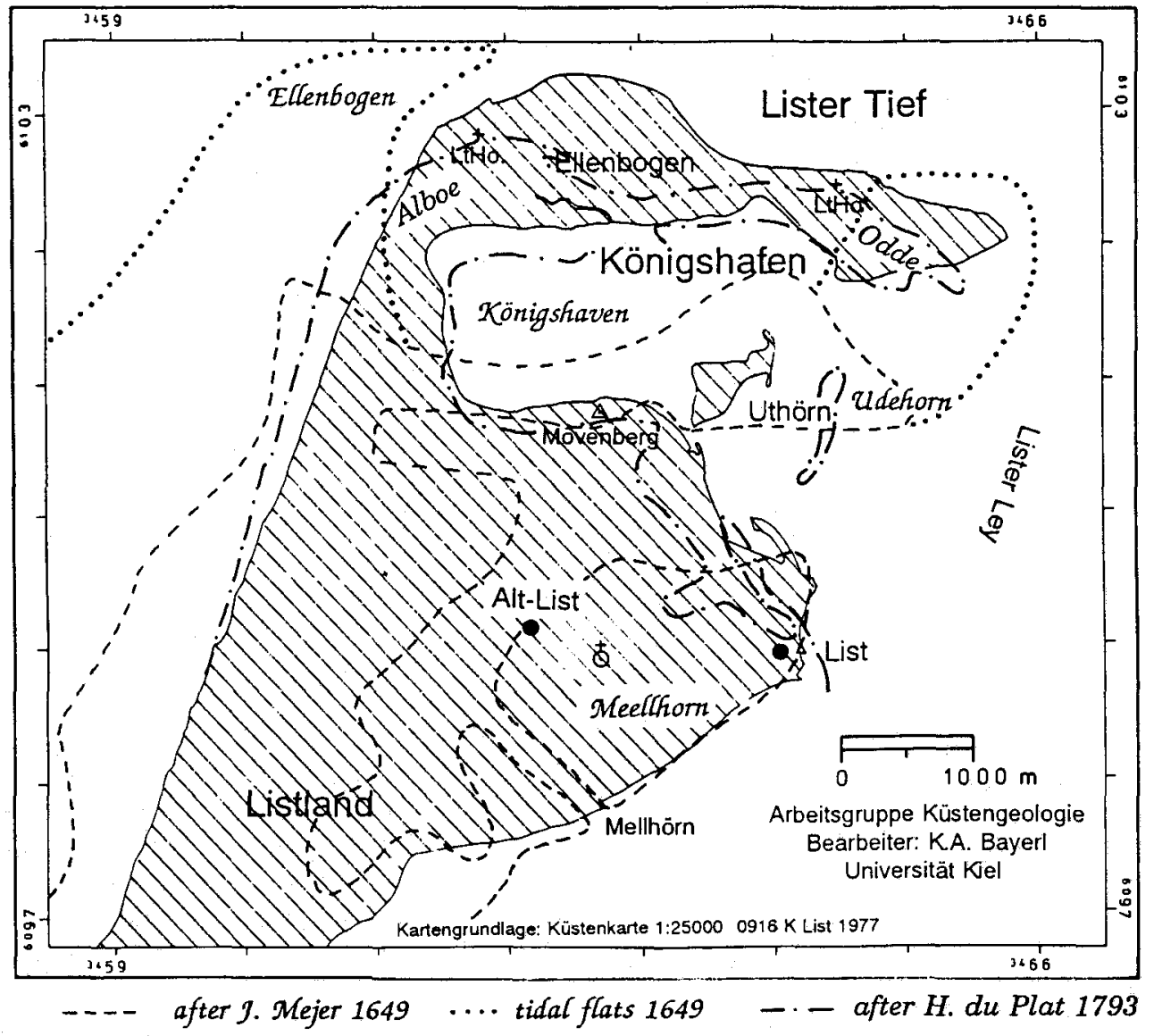

Fig. 10. Attempt at a reconstruction of different states of the "Listland" 
approximately in the central region of the "Listland" in a southerly direction. This had several indentations and a kind of "channel" toward the south-east which separated the island of "Meellhorn". "Alt-List", which vanished in the 14th century (Newig, 1980b), was probably situated on the western coast of "Meellhorn" and would have been protected from the shifting dunes in the west by the inlet. The "channel" running southeast of it, would have opened into the Wadden Sea in the low land region where the present settlement of "Mellhörn" is located. The ruin of the church of "Alt-List", mentioned for the first time by Du Plat et al. (1804/05), was accordingly situated at "Meellhorn", where, around 1600, the present village of List was founded (Booysen, 1828).

The map of Du Plat et al. (1804/05) essentially shows the present-day landscape with the "Ellenbogen". Du Plat et al. (1804/05) still differentiate between an "Ellenbogen" ("Alboe") and an "Odde" in the eastern region. Summarizing the geological findings, the present dune-covered "Ellenbogen", which was formed extraordinarily fast with the probable incorporation of sands and remains of former islands, could be a comparatively young formation, dating from the middle of the 17 th century to the end of the 18th. Already the maps of Hegelund und Sörensen at about the end of the 17th century probably show the neck of the "Ellenbogen", so that the "Alboe" itself would have been created in less than 50 years. Thereby, the initial stage of the present "Ellenbogen" could have been formed very fast after a short period of calm, current processes in the "Lister Tief", due to the formation of the "Vortrapptief" between Sylt and Föhr by the heavy storm floods at the beginning of the 17th century (Ahrendt, 1992; Zausig, 1939).

On the map of Mejer of 1649, this sand reef extends into the intertidal region, approximately as far as the recent "Ellenbogen", northwards into the "Lister Tief". Thereby, the former "Königshafen", which was not yet separated by the "Ellenbogen" from the "Lister Tief", was well protected and could have nevertheless been deep enough to be a harbour, and also the site of the sea battle that took place in 1644 .

The present Königshafen would consequently be a comparatively young formation and, following the isolation from the "Lister Tief", an area dominated by sedimentation.

\section{DISCUSSION}

The critical evaluation of historical maps appears to be rewarding, but will not provide any absolutely reliable conclusion as long as indications resulting from other investigation strategies are lacking. For a region like the "Listland" that was sparsely populated in former times, the maps give too few topographical reference points to reach even a low degree of preciseness.

Even with the help of the present drilling results, which are only fragmentary concerning the "Listland", definite proof of the basic changes of the landscape is not yet possible. Absolute datings of the series changes in Königshafen and the distinction of the presented sediment series below the "Listland", which are not available up to now, could throw more light upon this. The combination of cartographic results with geological findings allows both of the presented solutions to provide a reconstruction of the paleographic situation around 1650.

For this reason, the methods and results of the two parts of the investigation presented here were discussed; the differences between the two resulting conclusions, 
however, were clearly pointed out. This was done not least with the intention of meeting the obvious requirements of research by borings and datings - finally being able to give a reliable answer to questions of landscape genesis in the Königshafen region.

Acknowledgements. This entire investigation and evaluation has been financed by the Federal Ministry for Research and Technology in the context of the SWAP-project (publication no. 119 of the Ecosystem Research Wadden Sea). For this, and for the organization and supporting activities during the study, our special thanks are due to the project management and the "Steuergruppe" of the "Ecosystem Research in the Schleswig-Holstein Wadden Sea". We thank I. Austen and the "Amt für Land- und Wasserwirtschaft" in Husum for providing the records of the borings and the map material. Special thanks are due to D. Kaufhold for helping to draw the figures, L. Orlowski for the cartographical work, and finally to D. M. Fleet and C. Gätje for their expert work in translating our manuscript.

\section{LITERATURE CITED}

Ahrendt, K., 1992. Entwicklung und Sedimenthabitus des Hörnum- und Vortrapptiefs. - Meyniana $44,53-65$.

Austen, I., 1990. Geologisch-sedimentologische Kartierung des Königshafens (List auf Sylt) und Untersuchung seiner Sedimente. Dipl.Arb., Univ. Kiel, 99 pp.

Austen, I., 1992. Geologisch-sedimentologische Kartierung des Königshafens (List/Sylt). - Meyniana $44,45-52$.

Averdieck, F. R., 1980. Geobotanik des Sylter Holozäns, - Röm.-germ. Forsch. 39, 147-172.

Bayerl, K.-A., 1992. Zur jahreszeitlichen Variabilität der Oberflächensedimente im Sylter Watt nördlich des Hindenburgdammes. - Ber. Forsch.-TechnolZent. Westküste, Büsum 2, 1-134.

Booysen, J., 1828. Beschreibung der Insel Sylt in geographischer, statistischer und historischer Rücksicht. 1976, Taubstummen-Inst., Schleswig, 72 pp. (Repr. 1976. Schleswiger Druck- u. Verl.Haus, 24 pp.).

Danckwerth, C. D., 1963 (1652). Die Landkarten von Johannes Mejer, Husum, aus der neuen Landschaftsbeschreibung der Herzogtümer Schleswig und Holstein (Husum 1652). Hrsg. von K. Domeier \&. M. Haack. Heinevetter, Hamburg-Bergedorf.

Dietz, C. \& Heck, H.-L., 1952. Geologische Karte von Deutschland 1:25000, Land SchleswigHolstein. Erläuterungen zu den Blättern Sylt-Nord und Sylt-Süd, Kiel. Geologisches Landesamt Schleswig-Holstein, $110 \mathrm{pp}$.

Goldschmidt, P., Bayerl, K., Austen, I. \& Köster, R., 1993. From the Wanderdünen to the Watt: coarsegrained aeolian sediment transport on Sylt, Germany. - Z. Geomorph. 37, 171-178.

Gripp, K. \& Simon, W. G., 1940. Untersuchungen über den Aufbau und die Entstehung der Insel Sylt. I. Nord-Sylt. - Westküste $2(2 / 3), 24-70$.

Hansen, C. P., 1845. Die Insel Sÿlt in geschichtlicher und statistischer Sicht. Archiv f. Geschichte; Kiel, $203 \mathrm{pp}$.

Higelke, B., 1986. Geländeuntersuchungen im nordfriesischen Wattenmeer. Zur Korrektur einer historischen Karte von Johannes Mejer aus dem Jahre 1649. - Offa 43, 337-341.

Höck, M. \& Runte, K.-H., 1992. Historische Entwicklung von Schadstoffen im Sediment. - Jber. Forsch.-TechnolZent. Westküste, Büsum 1991, 53-57.

Hoffmann, D., 1975. Aufbau und Alter der Marsch im Kern der Insel Sylt. - Ber. Röm.-germ. Kommn $55,378-385$.

Jepsen, P., 1977. Jordsand. Bygd, Esbjerg, 59 pp.

Köster, R., 1979. Dreidimensionale Kartierung des Seegrundes vor den Nordfriesischen Inseln. In: Deutsche Forschungsgemeinschaft Forschungsbericht "Sandbewegung im Küstenraum". Boldt, Boppard, 146-168.

Kolumbe, E., 1933. Ein Beitrag zur Kenntnis der Entwicklungsgeschichte des Königshafens bei List auf Sylt. - Wiss. Meeresunters. (Kiel) 21 (2), 116-130.

Lang, A. W., 1968. Seekarten der südlichen Nord- und Ostsee, - Dt. hydrogr. Z. Erg. H. (B) 10, 1-105.

Lauridsen, P., 1903. Der Kartograph Johannes Mejer. - Veröff. nordfries. Ver. Heimatk. Heimatliebe $1,21-125$. 
Mager, F., 1927. Der Abbruch der Insel Sylt durch die Nordsee. - Veröff. Schlesw.-Holst. Univ. Ges. 8, 199.

Meyn, L., 1876. Geognostische Beschreibung der Insel Sylt und ihrer Umgebung. - Abh. geol. SpezKarte Preußen thüring. Staaten 1 (4), 1-155

Müller, F. \& Fischer, O., 1938. Sylt. In: Das Wasserwesen an der schleswig-holsteinischen Nordseeküste. II. Die Inseln. Reimer, Berlin 7, 1-304.

Newig, J., 1977. Die beste kartographische Darstellung des Herzogtums Schleswig am Ende des 18. Jahrhunderts - das kaum bekannte Kartenwerk von H. du Plat. - Heimat 12, 325-331.

Newig, J., 1980a. Sylt im Spiegel historischer Karten. - Röm.-germ. Forsch. 39, 64-84.

Newig, J., 1980b. Zur Entwicklung des Listlandes auf Sylt in den letzten drei Jahrhunderten - ein historisch-kartographischer Vergleich. - Nordfries. Jb. 16, 69-74.

Nienburg, W., 1927. Zur Ökologie der Flora des Wattenmeeres. 1. Der Königshafen bei List auf Sylt. - Wiss. Meeresunters. (Kiel) 20 (2), 144-199.

Priesmeier, K., 1970. Form und Genese der Dünen des Listlandes auf Sylt. - Schr. naturw. Ver. Schlesw.-Holst. 40, 11-51.

Reinke, J., 1903. Botanisch-geologische Streifzüge an den Küsten des Herzogtums Schleswig. Wiss. Meeresunters. (Kiel) 8 (Erg.-H.), 1-157.

Stremme, H. E., 1984. Die Insel Sylt im Eiszeitalter. In: Exkursionsführer Erdgeschichte des Nordund Ostseeraumes. Hrsg. von E. T. Degens, G. Hilmer \& C. Spaeth. Geol. Paläont. Inst., Hamburg, 283-296.

Willkomm, H., 1980. Radiokohlenstoff- und ${ }^{13} \mathrm{C}$-Untersuchungen zur Torfentwicklung und Meerestransgression im Bereich Sylt-Föhr. - Röm.-germ. Forsch. 39, 131-146.

Witt, R., 1982. Die Anfänge von Kartographie und Topographie Schleswig-Holsteins 1475-1652. Boyens, Heide, $96 \mathrm{pp}$.

Wolff, W., 1938. Die Entstehung der Insel Sylt. Friedrichsen, de Gruyter \& Co., Hamburg, 56 pp.

Zausig, F., 1939. Veränderungen der Küsten, Sände, Tiefs und Watten der Gewässer um Sylt nach alten Seekarten, Seehandbüchern und Landkarten seit 1585. - Geologie Meere Binnengewäss. 3, 401-505.

\section{MAPS}

Bugge, T. \& F. Wilster. (Hrsg. Det Kongelige Videnskabernes Societets Direction), 1805. Karte 9 "Kort over Tönder og Lugumscloster Amter samt Deele af Haderslebhuus Apenrade Flensborg og Bredsted Amter udi Hertugdömmet Schleswig".

Bundesamt für Seeschiffahrt und Hydrographie, 1993. Karte 108, "Lister Tief", Seekarte 1:50000, Hamburg.

Du Plat, H., F. Bauditz, F. Wilster \& Z. Tauenzien, 1804/05. Karte des Herzogthums Schleswig in XIV Blättern. (Hrsg. Landesvermessungsamt Schleswig-Holstein, 1983. Kiel). Karte "Lögumskloster, Westerland, Tönder".

Landesvermessungsamt Schleswig-Holstein, 1977. Blatt $0916 \mathrm{~K}$ " “List", $1: 25000$, Kiel.

Landesvermessungsamt Schleswig-Holstein, 1980. Blatt 916, "List", 1:25000, Kiel.

Danckwerth, C., 1652. Die Landkarten von Johannes Mejer, Husum, aus der neuen Landesbeschreibung der zwei Herzogtümer Schleswig und Holstein. Neu hrsg. K. Domeier u. M. Haack (Hamburg-Bergedorf 1963) Karte IV "Nordertheil des Herzogthumbs Schleswieg"; Karte IX "Westertheil des Amptes Haderschleben Zusambt Riepen und dem Löhmcloster 1649"; Karte XI "Das Ambt Tondern ohne Lundtofft Herde 1648"; Karte XIII "Landcarte von dem Nortfrieslande in dem Hertzogthumbe Sleswieg 1651".

Lang, A. W. (Hrsg.), 1973. Historisches Seekartenwerk der Deutschen Bucht. Karte 8, A. Haeyen, 1585. "Westküste". Karte 24, N. Hegelund, 1689. "Lister und Riber Tief". Karte 23, J. Sörensen, 1695. "Westküste". Karte 77 a, Grapow, 1869. "Übersichtskarte der Schleswig-Holsteinischen Westküste".

Reichs-Marine-Amt (Hrsg.), 1909. Karte 211, "Lister Tief", Seekarte 1:50 000. Berlin. 